\title{
Causes and spatio-temporal variations of non-natural mortality in the Vulnerable Spanish imperial eagle Aquila adalberti during a recovery period
}

Luis Mariano González, Antoni Margalida, Santi Mañosa, Roberto Sánchez, Javier Oria, José Ignacio Molina, Javier Caldera, Antonio Aranda and Luis Prada

\begin{abstract}
The analysis of 267 records of non-natural mortality of the Spanish imperial eagle Aquila adalberti over a 16-year period (1989-2004) shows an annual rate of 15.1 individuals found dead per year and that electrocution $(47.7 \%)$ and poisoning $(30.7 \%)$ were the most frequent causes of mortality. Most cases (91.7\%) were of human origin, and of those $92.3 \%$ were accidental. Just over half $(50.2 \%)$ were related to the transmission of electricity and human activity (collisions and electrocution), and $40.7 \%$ related to game practices and livestock protection (control of predators). No differences between sexes were found but subadults were electrocuted more frequently than expected whilst adults were poisoned more frequently. In breeding areas poison was the most frequent cause of mortality, whereas electrocution was the most common cause of death in dispersal areas.
\end{abstract}

Poisoning occurred more frequently than expected in the Northern and Southern regions compared to the WestCentral region. Electrocution was significantly more frequent in the West-Central region, and less common in the Southern region. The increase in electrocutions over the last few years is associated with previous non-permanent corrections on electricity power lines, whilst the increase in the cases of poisoning appears to be associated with the use of illegal poison in predator control by small game practices and for livestock protection. Permanent corrections in power lines and more research and awareness effort in the small game sector are recommended to reduce human-induced mortality in this Vulnerable species.

Keywords Aquila adalberti, electrocution, mortality, poisoning, Spain, Spanish imperial eagle.

\section{Introduction}

In Europe, although legislation has facilitated an increase in the populations of most raptor species

\footnotetext{
Luis Mariano González and Roberto Sánchez Dirección General para la Biodiversidad, Ministerio de Medio Ambiente, Gran Vía San Francisco 4, E-28005 Madrid, Spain.
}

Antoni Margalida (Corresponding author) Bearded Vulture Study and Protection Group, Apdo. 43, E-25520 El Pont de Suert Lleida, Spain. E-mai margalida@inf.entorno.es

Santi Mañosa Universitat de Barcelona, Facultat de Biologia, Avda. Diagonal, 645, E-08028 Barcelona, Spain.

Javier Oria c/San Agustín 22, E-40001 Segovia, Spain.

José Ignacio Molina Dirección General del Medio Natural, c/Rigoberto Cortejoso 14, 47071 Valladolid, Spain.

Javier Caldera Dirección General de Medio Ambiente, Apdo. Correos 7, 10181 Sierra de Fuentes, Cáceres, Spain.

Antonio Aranda Dirección General del Medio Natural, c/ Pintor Matías Moreno, 4, 45071 Toledo, Spain.

Luis Prada Dirección General del Medio Natural, Consejería de Medio Ambiente, c/ Princesa 3, 28008 Madrid, Spain.

Received 14 February 2006. Revision requested 1 August 2006. Accepted 10 October 2006.
(BirdLife International, 2004) some continue to be persecuted in certain regions (Pedrini \& Sergio, 2001; Holmes et al., 2003; Whitfield et al., 2003). Despite the fact that many causes of mortality have been recorded for birds of prey (Newton, 1979), most non-natural mortality can be attributed to direct persecution because of conflicts with human interests related to livestock rearing (Marquiss et al., 2003) and hunting (Redpath \& Thirgood, 2003; Viñuela \& Villafuerte, 2003). The causes of mortality in the Spanish imperial eagle Aquila adalberti, categorized as Vulnerable on the IUCN Red List (IUCN, 2006) and whose population on the Iberian Peninsula is estimated at 200 breeding pairs (González \& Oria, 2003), are known throughout its entire range for 1971-1977 (Garzón, 1974, 1977) and 1981-1988 (González, 1991), with accidental mortality from electrocution and poisoning and incidental mortality from shooting being the most important causes. Thus, a reduction of the mortality caused by human activities is a priority in the action plans and conservation strategies for this species (González, 1996; MMA, 2001; González \& Oria, 2003; Nagy \& Crockford, 2004).

Knowledge of the spatial and temporal patterns of causes of mortality constitutes an essential complement of demographic studies because it reveals causal factors 
that, directly or indirectly, influence survival rates (Caughley \& Gunn, 1996) and allows effects on population dynamics to be modelled and modified more effectively (Etheridge et al., 1997; Whitfield et al., 2004). Our aims here are to analyse (1) the causes of mortality of the Spanish imperial eagle and the temporal and spatial variation in mortality between 1989 and 2004, and (2) variation in mortality associated with the birds' age, sex, location and phenology.

\section{Methods}

The cases of 267 Spanish imperial eagles found dead and/or injured within their range during 1989-2004 were studied within the framework of Species' Recovery Plans in the Autonomous Communities of Castilla y León, Extremadura, Castilla-La Mancha and Madrid during the regular surveys of the species and electric power lines, and during the intensive monitoring of 84 individuals radio-tagged with VHF or satellite transmitters during 1990-2002. The cases were reported mainly by the Wildlife Recovery Centres of the above Autonomous Communities. Some cases were also reported by the Birds Migration Office and National Parks Department of the Environment Ministry and the Wildlife Forensic Laboratory (LFVS, Las Matas Madrid) and the National Institute of Toxicology. In addition some cases in the Andalusia region were obtained from published reports of the Doñana National Park (Environment Ministry and public reports) and reports and miscellaneous publications of this Autonomous Community.

For each recorded case we used, whenever possible, the information contained in the necropsy forms or reports. This consisted of data about the area, date of capture or death, the bird's age class, whether it was radio-tagged or not and the causes of its capture or death. The sex of live or injured individuals was determined with laparoscopic techniques using the amplification of gene CHD-W, in accordance with Ellegren's (1996) technique. Causes of mortality were classified by whether humans or any infrastructures of human origin were linked to the birds' death, and whether the cause was related to any type of human activity (e.g. game practices, livestock rearing, transport and industry). To examine variations in mortality due to age, individuals were categorized as (1) adults (birds with definitive adult plumage corresponding to an age of $>5$ years) and (2) subadults (birds with an age of $<5$ years). Subadults were further described as having first (1-2 years) or transition plumage (3-4 years) according to the age class categories established for the species (González, 1991; Forsman, 1999).

Temporal variation in mortality was studied by dividing the year according to the eagle's reproductive cycle (González, 1991; Margalida et al., 2007) into winter (January-March, i.e. courtship, pre-laying and incubation), spring (April-June, i.e. chick-rearing), summer (July-September, i.e. from the end of chick-rearing to the beginning of the young birds' independence), and autumn (October-December, i.e. in adults the period of reproductive inactivity and the beginning of courtship and, in first year eagles, dispersal).

Geographical variation of the cases considered was studied, firstly, with respect to the geographical location of the species' breeding nuclei (for details see González \& Oria, 2003; González et al., 2006c) and, secondly, with respect to whether the localities were in the species' breeding nuclei (the breeding zone) or species' juvenile dispersal areas (the dispersal zone; González \& Oria, 2003; González et al., 2006c). The breeding nuclei were grouped (Fig. 1) into three regions: the Northern (Guadarrama, Gredos and river Tiétar valley nuclei), Central (Montes de Toledo, Guadiana river, Sierras de Almaden and Extremadura nuclei), and Southern (South of Badajoz, Sierra Morena and Doñana-Guadalquivir marshes nuclei). Analysis of annual variation in mortality was carried out with respect to three periods differentiated by the population annual growth rate (L. González \& J. Oria, unpubl. data): 1989-1993 (first period of growth), 19941999 (period of stability) and 2000-2004 (new period of growth).

Analyses using $2 * 2$ contingency tables and $\chi^{2}$ tests examined the dependency between pairs of factors. The simultaneous independence of more than two categorical variables was examined using log-linear tests. The most suitable log-linear model was selected using the backward stepwise method (Bisquerra, 1989). Observed cell frequencies were considered to be significantly different from the expected frequencies when the absolute value of the standardized residual was greater than $Z_{\alpha / 2}(\alpha=0.05)$. Statistical analyses were carried out using SPSS (SPSS-Inc, 1996).

\section{Results}

Of the 267 cases of mortality, 52 were radio-tagged individuals (Table 1). Considering only the cases with a known cause of death $(n=241)$ there were no significant differences in cause of death between radio-tagged and non radio-tagged individuals $\left(\chi_{3}^{2}=7.04, \mathrm{P}=0.07\right)$. We therefore pooled radio-tagged and non radio-tagged records for further analyses. It was possible to determine the cause of death in $90.3 \%$ of the individuals (Table 1 ), with electrocution (47.7\%) and poisoning (30.7\%) being the most frequent causes. Of the remaining causes, only shooting $(6.6 \%)$ and disease $(5.4 \%)$ were particularly frequent. The annual rate of recorded cases (15.1\%) over 1989-2004 was almost double that recorded over 


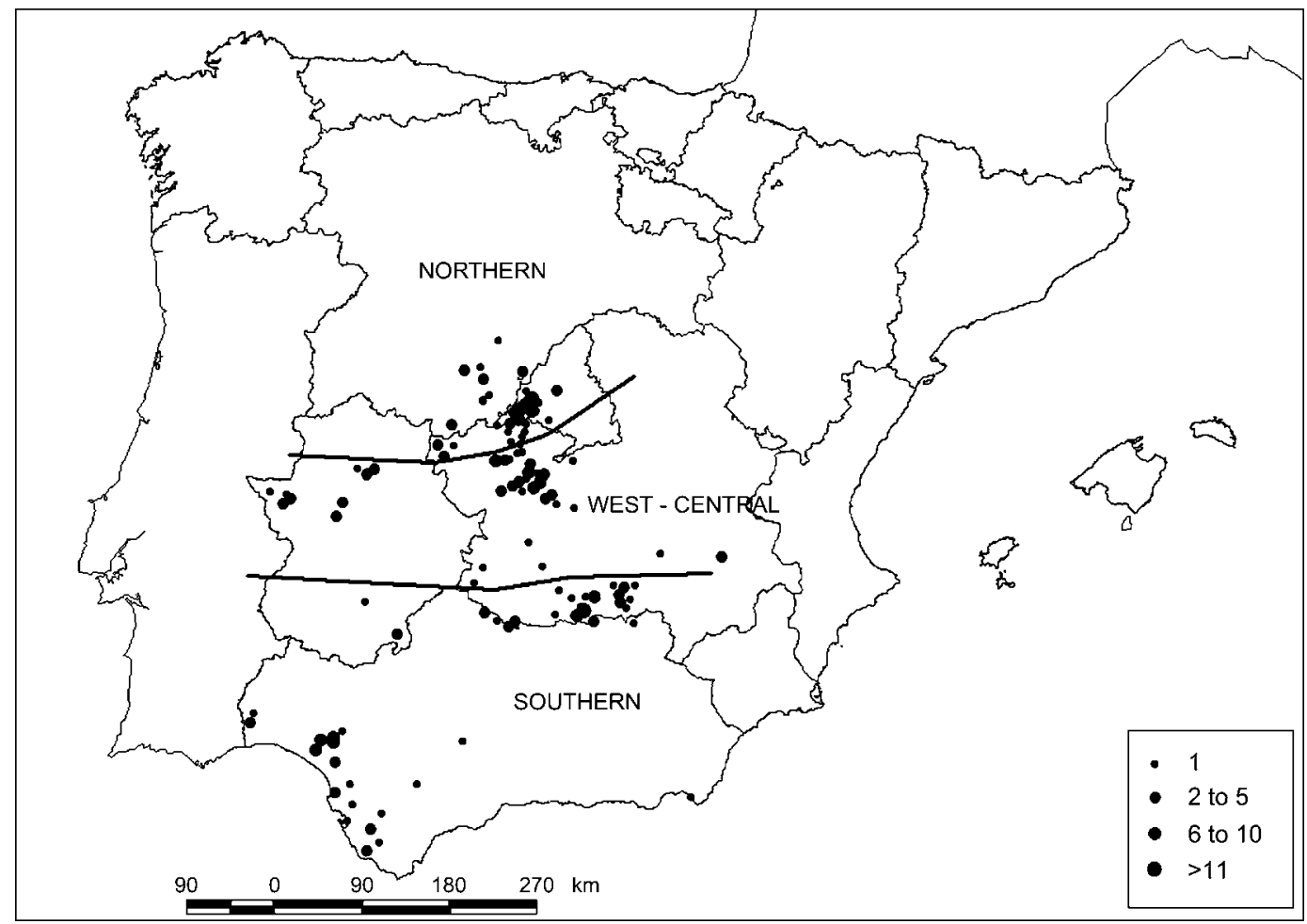

Fig. 1 Location of mortality cases (size of the circles, as per the legend, indicates the number of cases at each location) of the Spanish imperial eagle during 1989-2004, in three breeding regions (Northern, West-Central and Southern, see text for further details). The two lines indicate the boundaries between these regions.

1981-1987 (8.5\%; González, 1991), although the different effort and methodology used do not permit a statistical comparison. The causes of mortality in most of the cases $(91.7 \%)$ were of human origin; of these, accidental deaths (92.3\%) were the most common. Human activities most frequently linked with deaths were electrical power lines (50.2\%), game practices and livestock protection (40.7\%).

\section{Variation associated with individual factors: sex and age}

Out of 110 birds sexed $57(51.8 \%)$ were males and $53(48.2 \%)$ females, with the cause of death being known for 46 of the males and 53 of the females (Table 2). Considering all the known causes in the three main categories (poisoning, electrocution and other causes), no statistically significant differences were found between sexes for any of the causes $\left(\chi_{2}^{2}=1.86, \mathrm{P}=0.39\right.$; Table 2). There were significant differences in the cause of death between subadults and adults $\left(\chi_{2}^{2}=30.49\right.$, $\mathrm{P}=0.0001$; Table 2). Subadults were electrocuted more frequently than expected and adults were poisoned more frequently. In the 122 cases where the age of the subadults was known, the division between 1-2 and 3-4 years also revealed significant differences $\left(\chi_{2}^{2}=26.35\right.$, $\mathrm{P}=0.0001)$, with the 1-2 year old birds being more likely to die from electrocution $(57.6 \%, \mathrm{n}=99)$ and the 3-4 year olds from poisoning $(69.6 \%, n=23)$.

\section{Seasonal variations}

The maximum number of deaths occurred in autumn and winter (Table 2). The age-class ratio (subadults compared with adults) is highest in summer, just after the young leave the nest. Deaths of adults were recorded more frequently in winter and spring, and deaths of subadults more frequently in spring $\left(\chi_{3}^{2}=28.35\right.$, $\mathrm{P}<0.0001)$. The causes of mortality varied over the seasons $\left(\chi_{6}^{2}=37.59, \mathrm{P}<0.0001\right)$. Poisonings occurred more frequently than expected in winter and spring and less frequently in summer. Electrocutions, on the other hand, occurred most often in autumn and winter and less frequently the rest of the year. In summer there was a significant increase in deaths from other causes (Table 2).

\section{Spatial and inter-annual variations}

Causes of mortality were not independent of region $\left(\chi_{4}^{2}=20.01, \mathrm{P}=0.0004\right.$; Table 2$)$. Poisoning was relatively more frequent than expected in the Northern and Southern regions than in the West-Central, where it occurred less often than expected. Electrocution, on the 
Table 1 Frequency of different causes of mortality in the Spanish imperial eagle in radio-tagged and non radio-tagged individuals.

\begin{tabular}{|c|c|c|c|}
\hline Cause & Radio-tagged & $\begin{array}{l}\text { Non } \\
\text { radio-tagged }\end{array}$ & Total (n) \\
\hline \multicolumn{4}{|l|}{ Human origin } \\
\hline \multicolumn{4}{|c|}{ Game practices and livestock protection } \\
\hline Poisoned & 13 & 61 & 74 \\
\hline Shot & 5 & 11 & 16 \\
\hline Trapped & 3 & 2 & 5 \\
\hline Snared & 0 & 2 & 2 \\
\hline Captured in the field & 0 & 1 & 1 \\
\hline \multicolumn{4}{|l|}{ Energy industry } \\
\hline Electrocution & 19 & 96 & 115 \\
\hline Collision & 0 & 6 & 6 \\
\hline \multicolumn{4}{|l|}{ Transport industry } \\
\hline Accidents involving trains & 0 & 2 & 2 \\
\hline \multicolumn{4}{|c|}{ Non-human origin } \\
\hline Intraspecific aggression & 0 & 3 & 3 \\
\hline Starvation & 1 & 1 & 2 \\
\hline Disease & 5 & 8 & 13 \\
\hline Drowning & 2 & 0 & 2 \\
\hline \multicolumn{4}{|l|}{ Other } \\
\hline Unknown cause & 4 & 22 & 26 \\
\hline Total & 52 & 215 & 267 \\
\hline
\end{tabular}

other hand, was significantly more frequent in the WestCentral region and less common in the Southern. There were significant differences in the frequencies of cause of death between dispersal and breeding zones $\left(\chi_{2}^{2}=30.55, \mathrm{P}<0.0001\right.$; Table 2$)$. In the breeding zones poisoning was the main cause of mortality, whereas electrocution was the predominant cause in dispersal zones. The age and zone variables are not independent $\left(\chi_{1}^{2}=43.71, \mathrm{P}<0.0001\right)$, with subadults being found dead more frequently in dispersal zones than in breeding zones (124 compared with 41 individuals), and adults being found dead more frequently in breeding zones (11 compared with 37 individuals; Table 2).

The frequencies of the causes of death varied over time $\left(\chi_{4}^{2}=25.92, \mathrm{P}<0.0001\right)$, with electrocution being the most common cause during 1989-1993 and poisoning during 1994-1999 (Fig. 2). During 2000-2004 the cases of poisoning decreased, whilst the other causes of mortality increased. However, the existence of interactions between time, region and age factors make it hard to interpret the relations between these variables and the causes of mortality. In the West-Central region there were a significantly higher number of records of subadults than adults. This makes it difficult to interpret the connection between the frequencies and the causes of death. It is thus necessary to analyse the dependency between the Region and Cause variables separately for the different age classes. For the subadults, poisoning was significantly more frequent in the Northern region, whereas in the West-Central region electrocution was more common $\left(\chi_{4}^{2}=21.90, \mathrm{P}<0.0002\right)$. On the other
Table 2 Percentage of causes of death in the Spanish imperial eagle according to the different variables studied.

\begin{tabular}{llllc}
\hline & Poisoning & Electrocution & Others & Total (n) \\
\hline Sex & & & & \\
Male & 45.6 & 21.8 & 32.6 & 46 \\
Female & 45.3 & 32.1 & 22.6 & 53 \\
Subtotal (n) & 45 & 27 & 27 & 99 \\
Age & & & & \\
Subadult & 22.4 & 56.9 & 22.7 & 174 \\
Adult & 61.2 & 14.3 & 24.5 & 49 \\
Subtotal (n) & 69 & 106 & 48 & 223 \\
Season & & & & \\
Winter & 37.3 & 49.3 & 13.4 & 67 \\
Spring & 60.0 & 25.0 & 15.0 & 40 \\
Summer & 20.0 & 37.5 & 42.5 & 40 \\
Autumn & 23.3 & 64.4 & 12.3 & 73 \\
Subtotal (n) & 74 & 105 & 41 & 220 \\
Zone & & & & \\
Dispersal & 27.2 & 59.9 & 12.9 & 147 \\
Breeding & 41.0 & 23.1 & 35.9 & 78 \\
Subtotal (n) & 72 & 106 & 47 & 225 \\
Region & & & & \\
Northern & 45.3 & 37.5 & 17.2 & 64 \\
West-Central & 37.5 & 62.5 & 17.9 & 112 \\
Southern & 39.6 & 34.5 & 25.9 & 58 \\
Subtotal $(n)$ & 74 & 114 & 46 & 234 \\
Period & & & & \\
1989-1993 & 23.7 & 57.0 & 19.3 & 93 \\
1994-1999 & 53.4 & 33.3 & 13.3 & 75 \\
2000-2004 & 17.9 & 55.2 & 26.9 & 67 \\
Subtotal (n) & 74 & 115 & 46 & 235 \\
\hline & & & & \\
\hline
\end{tabular}

hand, in the case of adults, although poison was the main cause of death in all the regions and was proportionally more frequent in the Southern, the differences are not statistically significant $\left(\chi_{4}^{2}=4.15, \mathrm{P}=0.386\right)$. In the Southern and West-Central regions there was a scarcity of data for 1989-1993. On the other hand, during 2000-2004 there was a lack of information from the Northern region. Thus, it is necessary to analyse the temporal evolution of the causes of mortality independently for each region. There were no significant differences in the cause of death in the Northern region $\left(\chi_{4}^{2}=4.95, \mathrm{P}=0.292\right)$. In the West-Central region there were differences between the period 1989-1993, when electrocution predominated, and the period 1994-1999, when poisoning predominated $\left(\chi_{4}^{2}=12.37, \mathrm{P}<0.015\right)$. In the Southern region, the statistically significant differences appeared between 1994-1999, when there was a proportionally high frequency of poisoning, and 2000-2004 when there was a relatively high frequency of deaths attributable to other causes $\left(\chi_{4}^{2}=15.65, \mathrm{P}<0.0035\right)$.

\section{Discussion}

The study of the causes of death in birds of prey has used various methodologies that offer varying degrees 


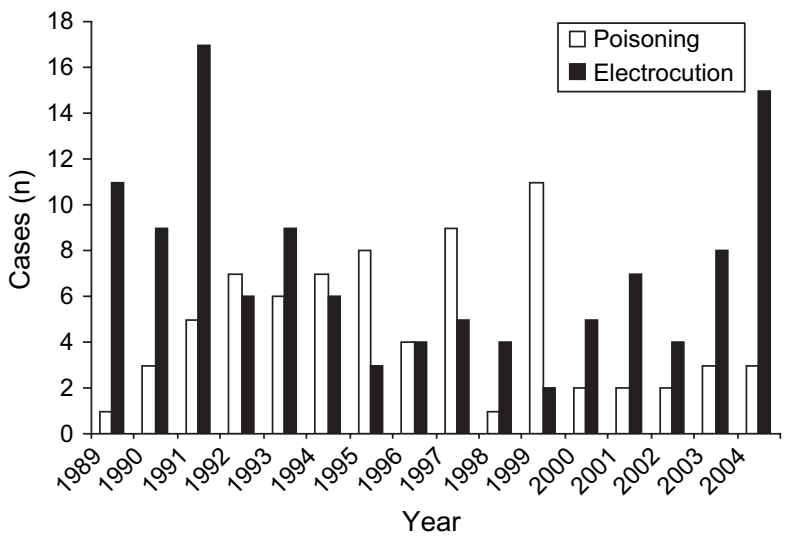

Fig. 2 Annual variation of the two most important causes of mortality in the Spanish imperial eagle during 1989-2004. White bars: poisoning; black bars: electrocution.

of reliability and bias (Newton, 1979). The best technique (because it involves minimal bias) is the monitoring of radio-tagged individuals. However, this is costly both with regards to time and money, and frequently provides limited results for a few individuals and is restricted to specific times and places (Kenward, 1993). The technique most commonly used to study raptor mortality is the analysis of non radio-tagged individuals found dead (Newton et al., 1999; Real et al., 2001) because it allows the maximum amount of information to be obtained in minimum time and covers larger geographical areas. However, this technique has a high level of bias (Elliot \& Avery, 1991; Franson \& Little, 1996; Franson et al., 1996). Our results suggest that records of non radio-tagged and radio-tagged individuals provide similar information on the frequency of the causes of mortality. Nevertheless, there is a trend towards a higher number of cases of death from shooting in radio-tagged individuals, which may indicate that deliberate persecution with shotguns could be less rare than the non radio-tagged records suggest. In this respect, in the $12 \%$ of dispersing juveniles that died from other causes, lead from hunting cartridges was found in their bodies, although their vital organs were not affected (M. Hernández, pers. comm.). Another factor that may have caused the number of deaths due to shooting to be underestimated is that they are harder to locate as they are usually hidden by the person responsible because such killing is illegal in Spain. Nevertheless, our results show that direct persecution was not the main cause of mortality, as it was in earlier periods (Garzón, 1974, 1977; González, 1991). The low incidence of mortality due to shooting is probably because of an increase in the conservation awareness of hunters (González \& Oria, 2004; Nagy \& Crockford, 2004) and a rise in conservation projects for the species with hunters' associations and on private land dedicated to game (González \& San Miguel, 2004). Such land holds c. $80 \%$ of the species' breeding population (L. González, unpubl. data).

On the other hand, non radio-tagged records may overestimate deaths related to electrical power lines. This could occur because, of all the mortality factors, this is the one that can be detected most easily as a result of the regular monitoring of power lines to check for bird mortality and the simple association between the appearance of the dead bird and the causal factor. The drop in mortality by electrocution that was recorded in the period 1995-2001 is clearly associated with the bird safety corrections on power lines carried out by the Autonomous Communities and the Environment Ministry in the framework of a Life Project of the European Union. In the Province of Madrid (Northern region), for example, in the years before the Life Project (1988-1994) up to 20 electrocutions of Spanish imperial eagles were recorded, and after the correction of electric pylons no more deaths were registered. The increase in the number of cases of electrocution in the last few years is associated with inadequate safety correction measures. In some provinces of the West-Central region (Toledo and Ciudad Real) the modifications of the electric pylons were carried out some years ago by insulating the power lines with heat shrink tape, a technique cheaper than the total replacement of the pylon but not permanent (Guzmán \& Castaño, 1998). Eight cases of mortality occurred because the insulating tape had worn away. On the other hand at least 11 cases of electrocution have been recorded in unmodified pylons that were considered to be safe in risk assessments (Unesa, 1989).

That subadults were electrocuted more frequently than adults and that adults were poisoned more frequently than subadults may have been due to: (1) a greater tendency by the different age classes to be victims of one or the other factor, or (2) a consequence of spatial segregation (dispersal or breeding zones) between age classes. Our results also suggest that electrocution occurs more frequently in autumn and winter. This may be because of the greater probability of young birds (the predominant age group at this time of the year) dying from electrocution and/or because the weather conditions in these seasons (e.g. higher rainfall, more clouds) make accidents with pylons more likely (Olendorff et al., 1980).

It has been suggested that among Spanish imperial eagles females are more likely to die from electrocution than males (Ferrer \& Hiraldo, 1991) but our results do not support this. However, our results indicate that subadults are more likely to die from electrocution than adults, as suggested previously (González, 1991), and this difference occurs principally during the first few years of the bird's life, and mainly in dispersal zones. 
The youngest individuals (1-2 years old) use predominantly treeless areas with an abundance of rabbits, coincident with areas with a higher degree of human exploitation and the presence of a high number of electrical power lines (González, 1991), unlike the areas occupied by adults characterized by a lower degree of human occupation and fewer power lines (González et al., 1992). In predominantly treeless areas pylons offer alternative perching sites and so the possibilities of the birds using them and thus dying from electrocution increase. That frequencies of mortality from electrocution and poisoning had different trends may be because, in the dispersal zones, pylons are abundant and available as perches whereas poisoned baits and carrion are not common. Thus the possibilities of a young bird reaching an area where the power lines have not been corrected, and it being electrocuted, are greater than the possibility of death from ingestion of a poisoned carcass. However, birds with higher manoeuvrability skills and/ or more neophobia would be those surviving to an old age. This could explain why in the first period (before the majority of power lines had been corrected) there was a higher percentage of electrocution, whilst in the second period, after the power lines had been modified, the number of cases of death from poisoning increased.

In the Spanish imperial eagle death from poisoning, contrary to what was recorded in 1981-1988 (González, 1991), is similar in importance to electrocution. In the three regions studied the adults and subadults (3-4 years old) were those most affected by this factor. In the cases of juveniles there are clear differences between the three regions studied: in the West-Central region electrocution is the main cause of death, whereas poisoning is the most frequent cause in the Northern and Southern regions, although only slightly more frequent than electrocution. Nevertheless, there is a positive association between poisoning and the Northern region and a negative association between electrocutions and the Southern region. That mortality from poisoning occurs more frequently than expected in winter and spring, coincident with the months in which illegal poison is used, suggests, as has been reported in other species and areas (Thirgood et al., 2000; Margalida et al., 2008), a cause-effect relationship between cases of poisoning and illegal methods to control predators. In this respect, the increase in the cases of poisoning recorded in the beginning of the 1990s coincides with a period of decreased wild rabbit and red-footed partridge Alectoris rufa populations, the most common small game species. On the other hand, an increase in the red fox Vulpes vulpes population (Viñuela \& Villafuerte, 2003), together with an increase in legal restrictions imposed on predator control practices, also coincides with the increase in use of illegal poisons. The notable reduction in the number of Spanish imperial eagle breeding pairs in some previously important breeding nuclei, such as Doñana (Southern region) and Valle del Tiétar and Sierras of Almadén (West-Central region; González \& Oria, 2003), can be explained by the considerable increase in mortality due to the use of poison in these zones during the study period (Hernández, 2003; Sergio et al., 2005).

Our results suggest that there is important spatial and temporal variation in the factors causing mortality in the Spanish imperial eagle and that the causal factors operate in different ways depending on the age of the bird. This implies that in the future conservation measures could be improved by applying more suitable management techniques in accordance with the zone (dispersal or breeding) and/or region (Northern, WestCentral or Southern). For example, despite the fact that conservation measures need to be applied throughout the whole of the species' range, more emphasis is required on the correction of power lines in the West-Central region, whilst greater emphasis on the eradication of the illegal use of poison is needed in the Northern and Southern regions.

In spite of the efforts of conservation agencies and the progress made in the last 2 decades, anthropogenic causes of mortality are still operating in most of the breeding and dispersal areas of the Spanish imperial eagle, and the control measures applied to conserve the species are not always as efficient as managers expect. The continued occurrence of direct and indirect persecution and the inadequate modification of power lines demonstrate this. Corrections of power lines should thus continue to be monitored to check how effective they are and priority should be given to the use of pylon designs safer for eagles, instead of temporary solutions. On the other hand, to reduce the illegal use of poison more research is needed to devise predation reduction techniques compatible with the conservation of threatened species such as the Spanish imperial eagle (Shivik et al., 2005; Muñoz et al., in press). Finally, although various conservation management actions have been carried out during the last few years (González et al., 2006a,b), our results suggest that permanent corrections to power lines and more research to reduce illegal poisoning are still necessary to reduce human-induced mortality in this Vulnerable species.

\section{Acknowledgements}

We are indebted to R. Moreno-Opo, J. Sánchez, A. Calvo, R. Jiménez, J.P. Castaño, J. Caballero, F. Robles, J.M. García, J.M. Tercero, F. Silvestre, L. García, C. Urdiales, C. Dávila, J.L. Moreno, J. Panadero, J. Guzmán, E. Morales, F. Güil and J.L. Freije for their help with the 
fieldwork. We would particularly like to thank V. García Matarranz. Thanks also to J.M. Blanco, N. Khadir, P. Garzón, J. Garzón, D. Martín, M. Fernández, I. Mosqueda, F. Sánchez, B. Ramos, J.L. González, J. Jiménez, A. Gómez, A. Rodríguez, A. Sánchez, M.J. Palacios, N. González, S. Centenera, B. Heredia and F. Jiménez and the official wardens and staff of the Wildlife Recovery Centres of the Autonomous Communities of Madrid, Castilla y León, Castilla-La Mancha and Extremadura for the information on sightings they kindly provided. We thank E. Ortega and L. Cardador for their help during the analysis of data and J.L. Tella and an anonymous reviewer for their comments. We also thank Tragsa, and the Fundació Bosch i Gimpera for administrative support. This study was jointly funded by the Dirección General para la Biodiversidad del Ministerio de Medio Ambiente and the Consejerías de Medio Ambiente of the above mentioned Autonomous Communities.

\section{References}

BirdLife International (2004) Birds in Europe: Population Estimates, Trends and Conservation Status. Conservation Series No. 12. BirdLife International, Cambridge, UK.

Bisquerra, R. (1989) Introducción conceptual al análisis multivaraible: un enfoque informático con los paquetes SPSS-X, BMDP, LISREL y SPAD, Volume II. PPU, Barcelona, Spain.

Caughley, G. \& Gunn, A. (1996) Conservation Biology in Theory and Practice. Blackwell, Oxford, UK.

Elliot, G.D. \& Avery, M.I. (1991) A review of reports of buzzard persecution 1975-1989. Bird Study, 38, 52-56.

Ellegren, H. (1996) First gene on the avian W chromosome (CHD) provides a tag for universal sexing of non-ratite birds. Proceedings of the Royal Society of London (B), 263, 1635-1641.

Etheridge, B., Summers, R.W. \& Green, R.E. (1997) The effects of illegal killing and destruction of nests by humans on the population dynamics of the hen harrier Circus cyaneus in Scotland. Journal of Applied Ecology, 34, 1359-1364.

Ferrer, M. \& Hiraldo, F. (1991) Man-induced sex biased mortality in the Spanish imperial eagle. Biological Conservation, 60, 57-60.

Forsman, D. (1999) The Raptors of Europe and the Middle East: A Handbook of Field Identification. T. \& A.D. Poyser, London, UK.

Franson, J.C. \& Little, S.E. (1996) Diagnostic findings in 132 great horned owls. Journal of Raptor Research, 30, 1-6.

Franson, J.C., Thomas, N.J., Smith, M.R., Robbins, A.H., Newman, S. \& McCartin, P.C. (1996) A retrospective study of post-mortem findings in red-tailed hawks. Journal of Raptor Research, 30, 7-14.

Garzón, J. (1974) Contribución al estudio del status, alimentación y protección de las Falconiformes en España Central. Ardeola, 19, 279-330.

Garzón, J. (1977) Birds of prey in Spain: the present situation. In Proceedings of the World Conference on Birds of Prey (ed. R.D. Chancellor), pp. 159-170. ICBP, Vienna, Austria.

González, L.M. (1991) Historial natural del Águila Imperial Ibérica (Aquila adalberti Brehm, 1861). Colección Técnica, ICONA, Madrid, Spain.

González, L.M. (1996) Action plan for the Spanish imperial eagle (Aquila adalberti). In Globally Threatened Birds in Europe:
Action Plans (eds B. Heredia, L. Rose \& M. Painter), pp. 175-189. Council of Europe, Strasbourg, France.

González, L.M., Arroyo, B.E., Margalida, A., Oria, J. \& Sánchez, R. (2006a) Effect of human activities on behaviour and success of breeding Spanish imperial eagles Aquila adalberti. Animal Conservation, 9, 85-93.

González, L.M., Bustamante, J. \& Hiraldo, F. (1992) Nesting habitat selection by the Spanish imperial eagle Aquila adalberti. Biological Conservation, 59, 45-50.

González, L.M., Margalida, A., Sánchez, R. \& Oria, J. (2006b) Supplementary feeding as an effective tool for improving breeding success in the Spanish imperial eagle (Aquila adalberti). Biological Conservation, 129, 477-486.

González, L.M. \& Oria, J. (2003) Águila imperial Ibérica, Aquila adalberti. In Atlas de las aves reproductoras de España (eds R. Martí \& J.C. del Moral), pp. 186-187. Dirección General de Conservación de la Naturaleza-Sociedad Española de Ornitología, Madrid, Spain.

González, L.M., Oria, J., Margalida, A., Sánchez, R., Prada, L., Caldera, J., Aranda, A. \& Molina, J.I. (2006c) Effective natal dispersal and age of maturity in the threatened Spanish imperial eagle Aquila adalberti: conservation implications. Bird Study, 53, 285-293.

González, L.M. \& San Miguel, A. (eds.) (2004) Manual de buenas prácticas de gestión en fincas de monte mediterráneo de la Red Natura 2000. Dirección General para la Biodiversidad, Ministerio de Medio Ambiente, Madrid, Spain.

Guzmán, J. \& Castaño, J.P. (1998) Electrocución de rapaces en líneas eléctricas de distribución en Sierra Morena Oriental y Campo de Montiel. Ardeola, 45, 161-169.

Hernández, M. (2003) Informe sobre los niveles de intoxicación en la fauna española. Grupo de Trabajo de Ecotoxicología, Dirección General para la Biodiversidad, Ministerio de Medio Ambiente, Madrid, Spain.

Holmes, J., Carter, I., Stott, M., Hughes, J., Davies, P. \& Walker, D. (2003) Raptor persecution in England at the end of the twentieth century. In Birds of Prey in a Changing Environment (eds D.B.A. Thompson, S.M. Redpath, A.H. Fielding, M. Marquiss \& C.A. Galbraith), pp. 481-485. The Stationery Office, Edinburgh, UK.

IUCN (2006) 2006 IUCN Red List of Threatened Species. IUCN, Gland, Switzerland [http://www.redlist.org, accessed 5 October 2007].

Kenward, R.E. (1993) Modelling raptor populations: to ring or to radio-tag? In Marked Individuals in the Study of Bird Population (eds J.D. Lebreton \& P.M. North), pp. 157-167. Birkhäuser Verlag, Basel, Switzerland.

Margalida, A., González, L.M., Sánchez, R., Oria, J., Prada, L., Caldera, J., Aranda, A. \& Molina, J.I. (2007) A long-term scale study of the breeding biology of Spanish imperial eagles. Journal of Ornithology, 148, 309-322.

Margalida, A., Heredia, R., Razin, M. \& Hernández, M. (2008) Sources of variation in mortality of the bearded vulture Gypaetus barbatus in Europe. Bird Conservation International, 18 , in press.

Marquiss, M., Madres, M. \& Carss, D.N. (2003) Whitetailed eagles (Haliaeetus albicilla) and lambs (Ovis aries). In Birds of Prey in a Changing Environment (eds D.B.A. Thompson, S.M. Redpath, A.H. Fielding, M. Marquiss \& C.A. Galbraith), pp. 471-480. The Stationery Office, Edinburgh, UK.

MMA (Ministerio de Medio Ambiente) (2001) Estrategia nacional para la conservación del aguila imperial ibérica (Aquila adalberti). 
Dirección General para la Biodiversidad, Ministerio de Medio Ambiente, Madrid, Spain.

Muñoz, J., Shivik, J.A., García, F., Lara, J. \& González, L.M. (in press) Evaluation of cage-traps and cable restraint devices to capture red foxes in Spain. Journal of Wildlife Management.

Nagy, S. \& Crockford, N. (2004) Implementation in the European Union of Species Action Plans for 23 of Europe's Most Threatened Birds. BirdLife International, Wageningen, The Netherlands.

Newton, I. (1979) Population Ecology of Raptors. T. \& A.D. Poyser, Berkhamsted, UK.

Newton, I., Wyllie, I. \& Dale, L. (1999) Trends in the numbers and mortality patterns of sparrowhawks (Accipiter nisus) and kestrel (Falco tinnunculus) in Britain, as revealed by carcass analyses. Journal of Zoology, 248, 139-147.

Olendorff, R.R., Motroni, R.S. \& Call, M.W. (1980) Raptor Management: The State of the Art in 1980. Bureau of Land Management Technical Note No. 345. US Department of Interior, Denver, USA.

Pedrini, P. \& Sergio, F. (2001) Density, productivity, diet, and human persecution of golden eagles Aquila chrysaetos in the central-eastern Italian Alps. Journal of Raptor Research, 35, 40-48.

Real, J., Grande, J.M., Mañosa, S. \& Sánchez-Zapata, J.A. (2001) Geographic variation of the causes of death of Bonelli's eagle Hieraetus fasciatus in Spain. Bird Study, 48, 221-228.

Redpath, S. \& Thirgood, S. (2003) The impact of hen harrier (Circus cyaneus) predation on red grouse (Lagopus lagopus scoticus) populations: linking models with field data. In Birds of Prey in a Changing Environment (eds D.B.A. Thompson, S.M. Redpath, A.H. Fielding, M. Marquiss \& C.A. Galbraith), pp. 499-510. The Stationery Office, Edinburgh, UK.

Sergio, F., Blas, J., Forero, M., Fernández, N., Donázar, J.A. \& Hiraldo, F. (2005) Preservation of wide-ranging top predators by site-protection: black and red kites in Doñana National Park. Biological Conservation, 125, 11-21.

Shivik, J.A., Martin, D.J., Pipas, M.J., Turnan, J. \& De Liberto, T.J. (2005) Initial comparison: jaws, cables, and cage-traps to capture coyotes. Wildlife Society Bulletin, 33, 751-755.
SPSS-Inc. (1996) SPSS Reference Guide 7.5. SPSS, Chicago, USA. Thirgood, S.J., Redpath, S.M., Rothery, P. \& Aebischer, N.J. (2000) Raptor predation and population limitation in red grouse. Journal of Animal Ecology, 69, 504-516.

Unesa (1989) Análisis de impactos de líneas eléctricas sobre la avifauna de espacios protegidos. Manual para la valoración de riesgos y soluciones. Estación Biológica de Doñana-UNESA, Madrid, Spain.

Viñuela, J. \& Villafuerte, R. (2003) Predators and rabbits (Oryctolagus cuniculus) in Spain: a key conflict for European raptor conservation. In Birds of Prey in a Changing Environment (eds D.B.A. Thompson, S.M. Redpath, A.H. Fielding, M. Marquiss \& C.A. Galbraith), pp. 511-526. The Stationery Office, Edinburgh, UK.

Whitfield, D.P., Fielding, A.H., MacLeod, D.R.A. \& Haworth, P.F. (2003) The effects of persecution on age of breeding and territory occupation in golden eagles in Scotland. Biological Conservation, 118, 249-259.

Whitfield, D.P., Fielding, A.H., McLeod, D.R.A. \& Haworth, P.F. (2004) Modelling the effects of persecution on the population dynamics of golden eagles in Scotland. Biological Conservation, 119, 319-333.

\section{Biographical sketches}

Luis Mariano González's research interests lie in the recovery of threatened species. Antoni Margalida has devoted most of his research to the behavioural ecology and conservation of vultures. Santi Mañosa has devoted most of his research to the ecology and conservation of birds of prey. Roberto Sánchez and Javier Oria are interested in the conservation of threatened birds of prey. José Ignacio Molina, Javier Caldera, Antonio Aranda and Luis Prada are responsible for the conservation and management of species and habitats in their Autonomous Communities. 